\title{
Prenatal and Postnatal Management of Congenital Pulmonary Airway Malformation
}

\author{
Mafalda David ${ }^{a}$ Ruben Lamas-Pinheiro ${ }^{a}$ Tiago Henriques-Coelho a, b \\ a Pediatric Surgery Department, Centro Hospitalar São João, and b Pediatric Department, Faculty of Medicine, \\ University of Porto, Porto, Portugal
}

\section{Key Words}

Congenital malformations - Lung development .

Macrocystic pulmonary lesion - Microcystic pulmonary

lesion · Thoracoscopic lobectomy · Lung cancer risk

\begin{abstract}
Congenital pulmonary airway malformation (CPAM) is one of the most common lung lesions detected prenatally. Despite the research efforts made in the past few years, controversy and lack of clarity in the literature still exist regarding nomenclature, classification, pathogenesis and the management of CPAM. Therefore, it is of greatest importance to delineate the natural history of CPAMs and to create a consensus to guide the management and follow-up of these lesions. This review will focus on classification systems, highlighting the most recent advancements in pathogenesis, and current practice in the prenatal diagnosis of CPAM. Strategies of prenatal management and postnatal management will be reviewed. Long-term follow-up, including lung cancer risk, is discussed and an outcome perspective is presented.

(c) 2016 S. Karger AG, Basel
\end{abstract}

(c) 2016 S. Karger AG, Basel

$1661-7800 / 16 / 1102-0101 \$ 39.50 / 0$

\section{Introduction}

Congenital pulmonary airway malformation (CPAM) - previously known as congenital cystic adenomatoid malformation (CCAM) - is a rare developmental malformation of the lower respiratory tract. It is accepted that abnormal airway patterning and branching during lung morphogenesis results in the appearance of lung cysts. Although the exact cellular mechanisms involved in the pathogenesis are unknown, many potential genes have been associated with the formation of lung cysts. Traditionally, Stocker's classification of CPAMs was based on the histopathological cyst diameter [1], but several other classifications have since emerged [2].

CPAM accounts for $95 \%$ of congenital cystic lung diseases and is the most common cystic lung lesion diagnosed by prenatal screening at 18-20 weeks of gestation [3]. A commonly quoted incidence of CPAMs is 1 per 25,000-35,000 live births [4]. However, with the advent of prenatal ultrasound (US), it is likely that the true incidence may have been underestimated because previously undiagnosed lesions are now being detected [5]. The management of symptomatic CPAMs is consensually

\section{KARGER}

E-Mail karger@karger.com

www.karger.com/neo
Tiago Henriques-Coelho

Pediatric Department, Faculty of Medicine

University of Porto

PT-4200-319 Porto (Portugal)

E-Mail thc@med.up.pt 
agreed, whereas the management of asymptomatic CPAMs is still contentious [6, 7]. In this review, CPAM classification systems, pathogenesis, prenatal and postnatal management strategies and long-term follow-up are presented.

\section{Challenging Diagnosis and Classification}

The description and classification of congenital lung cysts has evolved over time $[1,2,8,9]$. CCAM was originally described in 1949 by Ch'In and Tang [10] as a hamartomatous lesion characterised by an overgrowth of terminal bronchioles.

In 1977, three predominant histopathologic types (types I-III) were described by Stocker et al. [1] based on clinical, macroscopic and microscopic criteria. The microscopic features that distinguish CCAM from normal lung include: (i) proliferation of the terminal respiratory structures forming cysts; (ii) polypoid projections of the mucosa; (iii) increased smooth muscle and elastic tissue within cyst walls; (iv) absence of cartilage; (v) presence of mucous-secreting cells, and (vi) the absence of inflammation [1]. Improvements to this classification have been made, with additional types (types 0 and IV) being described [11]. Stocker also proposed changing the name of CCAM to CPAM, since the lesions are cystic in only three of the five types, adenomatoid in only one type, and as they represent malformations affecting different portions of the tracheobronchial tree. The main features of each type are summarised in table 1.

Several other classifications have also been purposed. Langston [8] divided lung cystic lesions into two types: (i) a large-cyst type (equivalent to Stocker's type I), and (ii) a small-cyst type (equivalent to Stocker's type II). A luminal obstruction with the secondary pulmonary dysplastic changes was proposed as a basis for these malformations $[8,12]$. Morotti et al. $[13,14]$ evaluated the cellular composition of different types of CPAM using immunohistochemistry, and divided the CPAMs into two major subtypes: one subtype consisting of CPAMs type I-III that show a bronchiolar-type epithelial differentiation, and the other type consisting of CPAM type IV, showing an acinar-alveolar epithelial differentiation.

Another classification was purposed by Adzick et al. [2] based upon the US appearance of the foetal lesion. Macrocystic lesions contain single or multiple fluid-filled cysts that are $5 \mathrm{~mm}$ or larger in diameter and tend to grow slowly and have a favourable prognosis (some foetuses with macrocystic lesions may develop hydrops). Micro- cystic lesions are smaller than $5 \mathrm{~mm}$ in diameter with a homogeneous echogenic appearance, with no visible cystic spaces. When microcystic lesions are large and grow rapidly, they are frequently associated with a mediastinal shift, pulmonary hypoplasia, polyhydramnios and hydrops. They are also frequently associated with a poor outcome [15-17]. This classification is especially useful since it has prognostic value, and can thus provide a practical guideline for the evaluation and treatment of prenatally diagnosed cases.

Bush [18] suggested a classification of cystic, intermediate or solid congenital thoracic malformation. The distinction between histological subgroups remains important, as some types of cancer are more common in some histologic types of CPAMs [19].

A great controversy exists regarding the correlation between clinical behaviour, prognosis and the CPAM type [20]. Stocker's classification was based upon 38 cases and reflects the pattern of the time since many of the lesions were characterised from autopsied infants with a predominance of type II and type III lesions [1]. Later studies showed that the prognosis of prenatally diagnosed lesions depends on the presence or absence of hydrops [21]. Other prognostic factors [2, 15, 22, 23] include: (i) the size of the lesion and its secondary effects (mediastinal shift, the extent of pulmonary hypoplasia, polyhydramnios, cardiovascular compromise); (ii) the degree of development of the unaffected lung, and (iii) the presence or absence of other congenital anomalies, such as extralobar sequestration, diaphragmatic hernia, pulmonary hypoplasia, cardiovascular malformation, hydrocephalus, skeletal malformation, jejunal atresia, bilateral renal agenesis/dysgenesis and Pierre Robin syndrome [11,24].

\section{Histopathology and Genetics}

Human lung growth starts as a primitive lung bud in early embryonic life and undergoes several morphological stages, which continue into postnatal life. Lung development begins at 3-4 weeks of gestation and occurs in six stages: the embryonic stage (4-7 weeks), pseudoglandular stage (5-17 weeks), canalicular stage (16-26 weeks), saccular stage (24-38 weeks), alveolar stage (36 weeks of gestation to 2 years of life) and microvascular maturation (birth to 2-3 years of age) [25-27]. Morotti et al. [13, 14] postulated that CPAM is caused by a focal arrest in lung development at different stages of the branching of the bronchopulmonary tree: the first subtype (CPAM bronchiolar types I, II and III) at the pseudoglandular stage 
Table 1. Pathological features of CPAM [11, 17, 24, 28, 104]

\begin{tabular}{|c|c|c|c|c|c|}
\hline Classification & Type 0 & Type I & Type II & Type III & Type IV \\
\hline $\begin{array}{l}\text { Descriptive } \\
\text { name }\end{array}$ & Acinar dysplasia & $\begin{array}{l}\text { Multiple large cysts or a single } \\
\text { dominate cyst }\end{array}$ & $\begin{array}{l}\text { Multiple evenly spaced cysts } \\
\text { (sponge-like appearance) }\end{array}$ & $\begin{array}{l}\text { Bulky firm mass } \\
\text { (adenomatoid } \\
\text { appearance) }\end{array}$ & Peripheral cyst type \\
\hline Frequency, \% & $1-3$ & $>65$ & $10-15$ & 8 & $10-15$ \\
\hline $\begin{array}{l}\text { Typical age at } \\
\text { presentation }\end{array}$ & Birth & $\begin{array}{l}\text { In utero, if large, to many years of age, } \\
\text { if small }\end{array}$ & 1st month of life & In utero or at birth & $\begin{array}{l}\text { Newborn to } 6 \text { years, or rarely } \\
\text { much later }\end{array}$ \\
\hline Presentation & Lungs will not aerate & $\begin{array}{l}\text { Newborn: respiratory distress, } \\
\text { mediastinal shift } \\
\text { Later: incidentally, or cough }+ \text { fever }+ \\
\text { infection }\end{array}$ & $\begin{array}{l}\text { Non-pulmonary anomalies may } \\
\text { supersede lung anomalies }\end{array}$ & $\begin{array}{l}\text { May be stillborn, or } \\
\text { severe neonatal } \\
\text { respiratory distress }\end{array}$ & $\begin{array}{l}\text { Respiratory distress } \pm \text { tension } \\
\text { pneumothorax, or infection/ } \\
\text { pneumonia, or incidental } \\
\text { finding }\end{array}$ \\
\hline $\begin{array}{l}\text { Cyst size (maximum), } \\
\mathrm{cm}\end{array}$ & 0.5 & 10.0 & 2.5 & 1.5 & 7 \\
\hline Cytodifferentiation & & $\begin{array}{l}\text { Bronchiolar-type epithelial } \\
\text { differentiation }\end{array}$ & & & $\begin{array}{l}\text { Acinar-alveolar epithelial } \\
\text { differentiation }\end{array}$ \\
\hline $\begin{array}{l}\text { Epithelial lining } \\
\text { (cysts) }\end{array}$ & $\begin{array}{l}\text { Ciliated } \\
\text { pseudostratified tall } \\
\text { columnar with } \\
\text { goblet cells }\end{array}$ & $\begin{array}{l}\text { Ciliated pseudostratified tall } \\
\text { columnar }\end{array}$ & Ciliated cuboidal or columnar & Ciliated cuboidal & Flattened alveolar lining cells \\
\hline $\begin{array}{l}\text { Muscular wall } \\
\text { thickness } \\
\text { of cysts, } \mu \mathrm{m}\end{array}$ & $100-500$ & $100-300$ & $50-100$ & $0-50$ & $25-100$ \\
\hline Mucous cells & Present in all cases & Present ( $33 \%$ of cases) & Absent & Absent & Absent \\
\hline Cartilage & Present in all cases & Present ( $5-10 \%$ of cases) & Absent & Absent & Rare \\
\hline Skeletal muscle & Absent & Absent & Present ( $5 \%$ of cases) & Absent & Absent \\
\hline $\begin{array}{l}\text { Lobar } \\
\text { involvement }\end{array}$ & All lobes involved & One lobe in $95 \%$; rarely bilateral & Usually one lobe & Entire lobe or lung & Usually one lobe \\
\hline Location & $\begin{array}{l}\text { Proximal } \\
\text { tracheobronchial } \\
\text { tree }\end{array}$ & $\begin{array}{l}\text { Proximal acinus (bronchial/ } \\
\text { bronchiolar) }\end{array}$ & Midacinus (bronchiolar) & $\begin{array}{l}\text { Bronchiolar/ } \\
\text { alveolar duct }\end{array}$ & $\begin{array}{l}\text { Distal acinus (alveolar saccular } \\
\text { regions) }\end{array}$ \\
\hline $\begin{array}{l}\text { Associated } \\
\text { anomalies }\end{array}$ & $\begin{array}{l}\text { CV anomalies, renal } \\
\text { hypoplasia, focal } \\
\text { dermal hypoplasia }\end{array}$ & Rare $(5-12 \%)$ & $\begin{array}{l}\text { CV anomalies, diaphragmatic } \\
\text { hernia, extralobar sequestration, } \\
\text { renal agenesis or dysgenesis } \\
(7-50 \%)\end{array}$ & & $\begin{array}{l}\text { No anomalies found to date } \\
{[24]}\end{array}$ \\
\hline Malignancy risk & No & BAC & No & No & PPB \\
\hline Prognosis & Lethal at birth & & & & \\
\hline
\end{tabular}

and the second subtype (CPAM type IV) at the saccular stage. Several molecular mechanisms underlying CPAM have been identified and have contributed to a better understanding of its pathogenesis. An increased cellular proliferation and decreased apoptosis in foetal CPAM specimens was demonstrated [28]. However, the authors failed to demonstrate differences in fibroblast growth factor (FGF)-7 expression, a growth factor previously implicated in experimental CPAM [29]. Liechty et al. [30] demonstrated that CPAMs resected in utero by the rapid growth and progression to hydrops had persistently elevated platelet-derived growth factor BB production.

Thyroid transcription factor 1 regulates early lung development [14] and correlates distinctive patterns of ex- pression in CPAMs: (i) types I-II presented a similar pattern to that in the pseudoglandular stage and (ii) type IV presented a pattern similar to that in the saccular stage. The glial cell-derived neurotrophic factor is another factor with abnormal expression in the epithelium lining the airways of immature human lungs [31] and could play a role in CPAM. Another potential gene, Hoxb-5, is involved in lung branching and has a higher level of expression in resected CPAM specimens, suggesting it has an abnormal temporal and spatial expression in CPAM [32]. Jancelewicz et al. [33] analysed gene expression from laser-dissected epithelium and mesenchyme of human foetal and postnatal CPAMs, and demonstrated an imbalance of the markers of early lung development, namely an 
increase in Hoxb-5, TTF1 and FGF9 expression, a decrease in FGF7, and no differences in FGF10 and FGF receptor 2 expression.

Another candidate gene is the fatty acid-binding protein FABP-7 [34], the expression of which is reduced in foetal CPAM specimens. An overexpression of Clara cell marker 10 was also identified [13]. Altered integrin cytoplasmic signalling was also proposed, since integrin and E-cadherin expression patterns were altered in CPAM tissue [35].

SOX2 is a transcription factor with a critical role in lung branching [36]. The overexpression of SOX 2 induces the appearance of cyst-like structures [37], and it is expressed in the epithelial lining of cystic lesions in CPAM type II, but not in CPAM type I [37].

Our group [38] was able to evaluate the formation of CPAM-like lesions in response to the overexpression of FGF10 in the mesenchymal compartment of developing foetal rat lung. The overexpression of FGF10 at different locations and developmental stages induced the appearance of localised cystic malformations, ranging from macrocystic malformations lined by predominantly bronchial epithelium, to focal microcystic malformations lined by predominantly alveolar epithelium. The similarity of these lesions to human CPAMs strongly suggests that the overexpression of FGF10 may be one of the most important mechanistic components of the initial events in CPAM formation. However, the initial 'hit' that induces FGF10 overexpression remains to be determined.

The emergence of hybrid lesions has been widely reported in the past few years, leading to speculation of a possible link between these lung malformations $[9,12$, 39]. Cass et al. [9] described prenatally diagnosed lung masses that display clinicopathological features of both CPAM and bronchopulmonary sequestration (BPS), suggesting a common embryologic basis for hybrid lesions. Langston [8] postulated that in utero airway obstruction is the basis and the unifying mechanism for congenital lung malformations. It is possible that the level, the completeness and the timing of airway obstruction together with secondary pulmonary dysplastic changes may explain the varied spectrum of hybrid lung malformations.

\section{Diagnosis}

\section{Prenatal Diagnosis}

Prenatal diagnosis has evolved over the years. Today, routine prenatal US screening complemented with magnetic resonance imaging (MRI) has become increasingly valuable in detecting CPAMs [40], with an accuracy of $65-91 \%[41,42]$. Before the advent of prenatal sonography, CPAMs were diagnosed only in symptomatic infants or as an incidental finding. The improvement of prenatal diagnosis has led to the identification of many asymptomatic neonates, creating new management challenges [43]. The major advantage of prenatal diagnosis is the identification of symptomatic neonates [44], prenatal counselling, foetal intervention and birth planning [41].

US is the antenatal imaging modality of choice to screen CPAMs, while MRI is an excellent option for the morphological and volumetric evaluation of the foetal lung [6]. CPAMs appear as hyperechoic, heterogeneous tissue with multiple hypoechoic cysts that may differ in size and number on foetal US. MRI returns a higher signal than with a normal lung on T2-weighted images [45]. Depending on the CPAM lesion type, foetal MRI can show a homogeneous or heterogeneous T2-hyperintense lesion containing cystic spaces and vascular architectural distortion [46]. Recently, Epelman et al. [47] recommended a description protocol that includes: (i) anatomical location, (ii) relationship with the bronchial tree, (iii) number of cysts and (iv) size of the largest cyst, among other parameters. US in the second trimester is reliable and accurate in detecting echogenic pulmonary lesions, and differential diagnosis includes CPAM, BPS, bronchogenic or neurenteric cysts, and diaphragmatic hernia [17]. When the US findings are equivocal or the images are difficult to interpret, such as in late pregnancy or with an inaccessible foetal position, MRI should be considered [46]. MRI plays an important complementary role to US since it is able to define the type and extent of these lung lesions, thus guiding prenatal intervention and postnatal care [46].

Colour Doppler US has been suggested as a tool to investigate systemic arterial blood supply. It evaluates the arterial and venous blood flows, allowing prenatal differentiation between CPAM and BPS. While CPAMs derive their blood supply from the pulmonary circulation and drain via the pulmonary veins, BPS has a feeding systemic artery [9]. However, two-dimensional colour Doppler US is not $100 \%$ sensitive for identification of the feeding artery [48].

The natural history of prenatal cystic lung lesions varies from complete regression in utero to life-threatening hydrops fetalis. The timing of 'regression' is variable but tends to be in the mid-third trimester, usually at 32-34 weeks of gestation [49].

Hydrops is the strongest prognostic factor and it may be an indication for prenatal intervention [50]. A survival rate of more than $95 \%$ of CPAM cases without hydrops 
has been reported, whereas death occurred before or after birth in $95 \%$ of CPAM cases with hydrops managed expectantly [51]. The development of hydrops is typically limited to those foetuses with very large chest masses with mediastinal shift and vena cava obstruction [15, 46, 52, 53]. Hydrops is commonly associated with ascites, pleural and pericardial effusions, and skin and scalp oedema. Anasarca and placentomegaly appear in advanced cases $[54,55]$. Three features were found to be highly specific for foetal hydrops in foetuses with large masses: a massthorax ratio of at least $56 \%$, cystic predominance and diaphragm eversion [21]. Gigantic foetal lung lesions have also other pathophysiologic consequences, including oesophageal compression by the thoracic mass, which interferes with amniotic fluid swallowing and results in polyhydramnios $[15,56]$.

Crombleholme et al. [52] reported a useful tool to stratify the risk of hydrops, the need for foetal intervention and the perinatal survival rate. Sonographic measurement of the CPAM volume ratio (CVR) is an index estimated as the CPAM volume divided by the head circumference. A CVR greater than 1.6 predicts an increased risk for hydrops fetalis, while a CVR less than or equal to 1.6 in the absence of a dominant cyst is associated with a less than $3 \%$ risk of hydrops. The growth rate of the lesion, particularly when associated with a macroscopic cyst, is also a risk factor for developing hydrops. Approximately $40 \%$ of CPAMs increase in size during pregnancy, with the most rapid growth occurring during 20-26 weeks of gestation, after which growth peaks and plateaus $[52,53]$. The gestational age at diagnosis will impact surveillance frequency since microcystic CPAMs tend to regress spontaneously after the growth peak [15], while macrocystic lesions generally do not regress [52].

\section{Postnatal Diagnosis}

Imaging evaluation and clinical follow-up after birth is required in all cases to confirm the diagnosis and to initiate adequate treatment $[23,56]$. Other imaging techniques like chest X-ray and computed tomography (CT) scan may have a role in postnatal assessment [57].

An apparent involution of lung lesions on serial prenatal US or neonatal chest radiographs can be misleading and does not rule out CPAM persistence on a postnatal CT scan $[50,58]$. Prenatal US becomes less sensitive in diagnosing lung cysts with advancing pregnancy due to the loss of the fluid-tissue interfaces. Postnatally, thinwalled cystic lesions are difficult to see on a plain radiograph when uninfected and, thus, a chest CT for definitive diagnosis is strongly recommended in all cases [50,

Prenatal and Postnatal Management of CPAM
$54,59,60]$. The radiological image of a CPAM depends on the consistency of the lesion: hyperlucent in multicystic regions (particularly types I and II), radiopaque in solid components (especially type III), or air fluid level in the early neonatal period when the pulmonary fluid is clearing or in infected lesions [61]. On a CT scan, solid CPAMs or those that have cysts filled with fluid will be hyperdense, whereas lesions that are overinflated will have a hypodense appearance [57].

Postnatal follow-up should also include the evaluation of associated congenital anomalies and here a CT scan is generally the choice $[61,62]$. In asymptomatic patients, a CT scan is advised during the first 3 months of life. It has several advantages, including a faster acquisition, the reduced need for sedation, is less expensive and is very useful in adequate planning of the surgery [47]. Angiography CT can be extremely useful in the differential diagnosis of congenital lung malformations [47]. MRI could be an alternative to a CT scan, but there is no available evidence showing which one is the best technique [60].

After surgical resection or in cases of asymptomatic stable lesions when a conservative 'wait and see' approach is adopted, the patient should be followed up until adulthood. The most acceptable imaging technique used in the follow-up is CT and further work is needed to evaluate the potential role of MRI. Although CT is largely accepted, doubts arise on the frequency of the scans, since the benefit of repeated CT scans needs to be balanced against the risks of ionising radiation [47].

\section{Management}

\section{Prenatal Management}

Prenatal treatment options include the maternal administration of steroids, minimally invasive procedures or open foetal surgery. These interventions aim to alleviate the mass effect, prevent the progression of complications and to improve the outcome for these foetuses [63]. In macrocystic lesions, decompression can be attempted by permanent drainage via a thoracoamniotic shunt (TAS) placement guided by US or single-needle thoracocentesis [64]. In microcystic lesions, open foetal surgery may be indicated [63]. Maternal betamethasone treatment has been suggested to have beneficial effects on large microcystic CPAMs [65-67]. Before a decision for any prenatal intervention is taken, it is recommended to characterise the lesion (macro vs. micro, CVR, hydrops) and to identify associated anomalies by US, echocardiogram and/or MRI $[68,69]$. 
Prenatal Steroids

Resolution of a large CPAM after steroid therapy, initially given for lung maturation, was first described by Higby et al. [70] in 1998. Another group reported the unexpected resolution of hydrops after maternal betamethasone administration [66]. Several others reported the same effect with two standard doses of $12 \mathrm{mg}$ of betamethasone intramuscularly, $24 \mathrm{~h}$ apart, showing a decrease in CPAM growth lesions with CVR $\geq 1.4$ at $19-26$ weeks of gestation $[66,71]$. The mechanism of the effect of steroids on CPAM is unknown. Curran et al. [67] hypothesised that steroids stimulate the maturation of the lung cells. Others have speculated that the steroids affect the cell proliferation and apoptosis, thus reducing CPAM growth [72].

Current evidence suggests that in large CPAMs with hydrops, a course of steroids appears to be a reasonable first-line therapy. However, a variable response on maternal betamethasone treatment has also been reported [72, 73]. For a subset of high-risk CPAMs that do not adequately respond to a single course of steroids, multiple courses of antenatal betamethasone may facilitate the stabilisation or regression of CPAM [73]. Whether steroids should also be used in CPAMs without hydrops is more questionable, as the prognosis without intervention is generally good and spontaneous regression may occur $[55,63]$.

The long-term effects of maternal betamethasone on foetal development are a concern, but there are no studies to support deleterious effects occurring following one or two courses of maternal betamethasone [74]. Betamethasone seems to be a good choice since it does not cause decreased alveolarisation, as compared to dexamethasone $[74,75]$.

\section{Foetal TAS}

Large lesions carry a significant risk of pulmonary hypoplasia and foetal hydrops. These cases can be managed with TAS $[17,51,63,76]$, which has been recommend in severe cases with high-risk hydrops, even before it develops [76]. This issue is still controversial since it is difficult to predict the evolution of a macrocystic lung lesion and there are no randomised studies comparing treatment with the non-treatment of non-hydropic foetuses.

The criteria for TAS placement are: (i) gestational age $<32$ and $>20$ weeks (if performed at less than 20 weeks, it may increase the risks of chest wall deformity); (ii) nonimmune hydrops, i.e. pleural effusion (PE) associated with either skin oedema or ascites); (iii) isolated PE without hydrops occupying a large part of the thoracic cavity
$(>50 \%)$ and causing mediastinal deviation, rapidly increasing in size or being associated with increasing polyhydramnios, or rapidly re-accumulating after thoracocentesis; (iv) large bilateral PE with a suspicion of pulmonary hypoplasia; (v) macrocystic CPAM with a dominating cyst with a high risk of pulmonary hypoplasia (CVR $>1.6$ indicates much higher risk), and (vi) the absence of other associated major foetal anomalies detected by US for laboratory analysis $[53,77]$. TAS complications include foetal or uterine wall trauma, displacement or occlusion of the catheter, amniotic fluid leakage, infection, premature delivery and foetal demise [77-79]. Squamous metaplasia of the cyst epithelia has also been described [80]. The outcome of TAS has been reported in 68 foetuses with macrocystic CPAMs, two thirds of which were hydropic [51]. The overall survival rate was 75\%: $68 \%$ in hydropic and $87.5 \%$ in non-hydropic foetuses [51].

\section{EXIT Procedure}

The ex utero intrapartum (EXIT) procedure is well described [81-83] and was first developed for reversing tracheal occlusion in foetuses with severe congenital diaphragmatic hernia $[84,85]$. An experienced multidisciplinary team is crucial for successful EXIT procedures [86]. The hallmark of the EXIT procedure remains a prolonged uterine relaxation with deep inhalational anaesthesia, leading to preservation of the uteroplacental blood flow and gas exchange $[87,88]$. This technique allows a controlled resection of large foetal lung lesions at delivery, limiting complications due to cardiac tamponade and acute respiratory failure [89].

The major indication for EXIT delivery includes the presence of a foetal lung mass with severe mediastinal shift and/or hydrops associated with a persistently elevated CVR (mean 2.2, with a range of 1.0-2.6) after 32 weeks of gestation $[69,89,90]$. Even after resolving hydrops with maternal steroids administration, there is a risk of pulmonary hypoplasia. In some cases, the size of the CPAM remains significantly high with a mediastinal shift and cardiac compression. In these cases, the EXIT procedure may also be indicated and the delivery should be planned for a tertiary care centre $[69,91]$.

Hedrick et al. [89] reported an overall survival after EXIT lung mass resection of $89 \%$, with the mean gestational age at the EXIT delivery of 35 weeks $[89,92]$. Complications are primarily related to a failure to preserve uteroplacental gas exchange or a loss of myometrial relaxation [87]. An advantage is the possibility to start surfactant replacement therapy before delivery [82]. Maternal 
postoperative morbidity is comparable to caesarean section under general anaesthesia, with a minimal increased likelihood of maternal anaemia [77].

\section{Prenatal Management Algorithm}

A prenatal management algorithm, based on all possible foetal interventions and imaging tools, is proposed (fig. 1).

\section{Postnatal Management}

Significant advances in neonatal intensive care have allowed support, either with conventional ventilation or high-frequency oscillation ventilation, optimising oxygen delivery. A postnatal echocardiogram is essential for assessing cardiovascular function and for guiding inotropic support, especially in the case of persistent pulmonary hypertension of the newborn. Extracorporeal membrane oxygenation can be an option in challenging cases despite full cardiorespiratory support.

\section{Surgical versus Conservative Approach}

Every patient with CPAM should be evaluated for surgery. If the patient is symptomatic, surgical treatment is recommended. Some newborns with large lesions may even require a neonatal surgical resection in order to save viable lung parenchyma and reverse mediastinal displacement [93].

The management of asymptomatic CPAM remains contentious and no consensus has yet been reached regarding the optimal timing for surgery [4, 15, 94-97]. Some authors adopt an early resection strategy to avoid the onset of symptoms $[4,15,98,99]$ since the safety of lung resection during the infantile period has been proven $[41,98,100]$, while others adopt a conservative strategy, recognising the surgical risks and the potential of overtreatment [97, 101-103], and surgery is only purposed after the patient becomes symptomatic with recurrent infections or pneumothorax $[100,104]$. Additionally, some authors recognise the potential for spontaneous resolution: in a study of 56 children with an antenatal diagnosis of CPAM, two CPAMs spontaneously resolved postnatally and ten resolved antenatally [104]. The elective and early resection of asymptomatic lung malformations is based on several arguments: (i) an early lobectomy avoids long periods of observation, preventing the need for using ionising radiation in repeated imaging studies and the loss of patients during follow-up; (ii) if no imaging technique is able to confirm the pathological diagnosis; (iii) the possible relation of CPAM with lung malignancy development, and (iv) a potential compensatory lung growth [105].

Prenatal and Postnatal Management of CPAM
Long periods of observation increase the risk of complications $[15,106]$. In asymptomatic patients following the neonatal period, a $3.2 \%$ complication rate was estimated, and occurred at a median age of 7 months [107]. In fact, recurrent infections may impose technical difficulties at the time of lung resection [98, 100, 108]. Furthermore, it has been shown that the infection alone may lead to pulmonary growth impairment [105].

The potential for compensatory lung growth is one of the main arguments for early lung resection [105, 109111]. Postnatal lung development consists of three stages: (i) stage I (birth to 1-2 years) with alveolar proliferation and a rapid increase in alveoli number; (ii) stage II (2-3 years) with microvascular maturation and proliferation, and (iii) stage III with late alveolarisation and alveolar maturity $[109,111]$. Alveolar multiplication is fastest during the first 2 years of age, then slows at 4 years and stops at around 8 years of age $[109,112]$. Stage I is suggested to be the most important period regarding future lung function. Two mechanisms of lung growth can occur after surgery: compensatory alveolar multiplication or overinflation of the remaining parenchyma [113]. A radionuclide imaging study suggested that alveolar multiplication mainly occurs after lobectomy in patients younger than 1 year, while emphysematous overinflation mainly occurs when lobectomy is performed after the age of 1 year [105]. This study also suggested that recurrent and severe infection alone influences pulmonary function. However, a retrospective study showed that age at the time of lobectomy (before vs. after 2 years) did not influence the spirometer results at a mean age of 10 years [113]. If resection is endorsed, most authors agree on surgery during the first year of life. Some authors wait until 6 months of age [114], while others propose a much earlier intervention at 4 weeks of age [68].

\section{Thoracotomy versus Thoracoscopy}

A meta-analysis comparing thoracoscopy with the open resection of CPAM suggested no differences between thoracotomy and thoracoscopy regarding overall complications and surgery duration. A reduction in length of hospital stay and in days spent with a chest tube was observed after the minimal invasive approach [115]. The largest study, reviewing 97 lobectomies, revealed longer operative times in thoracoscopic procedures but a shorter hospital stay, better cosmesis and decreased postoperative pain. Larger randomised trials are required in order to compare both approaches. In the current minimal invasive era, data is consistent regarding resection safety and feasibility. In experienced hands, the thoraco- 


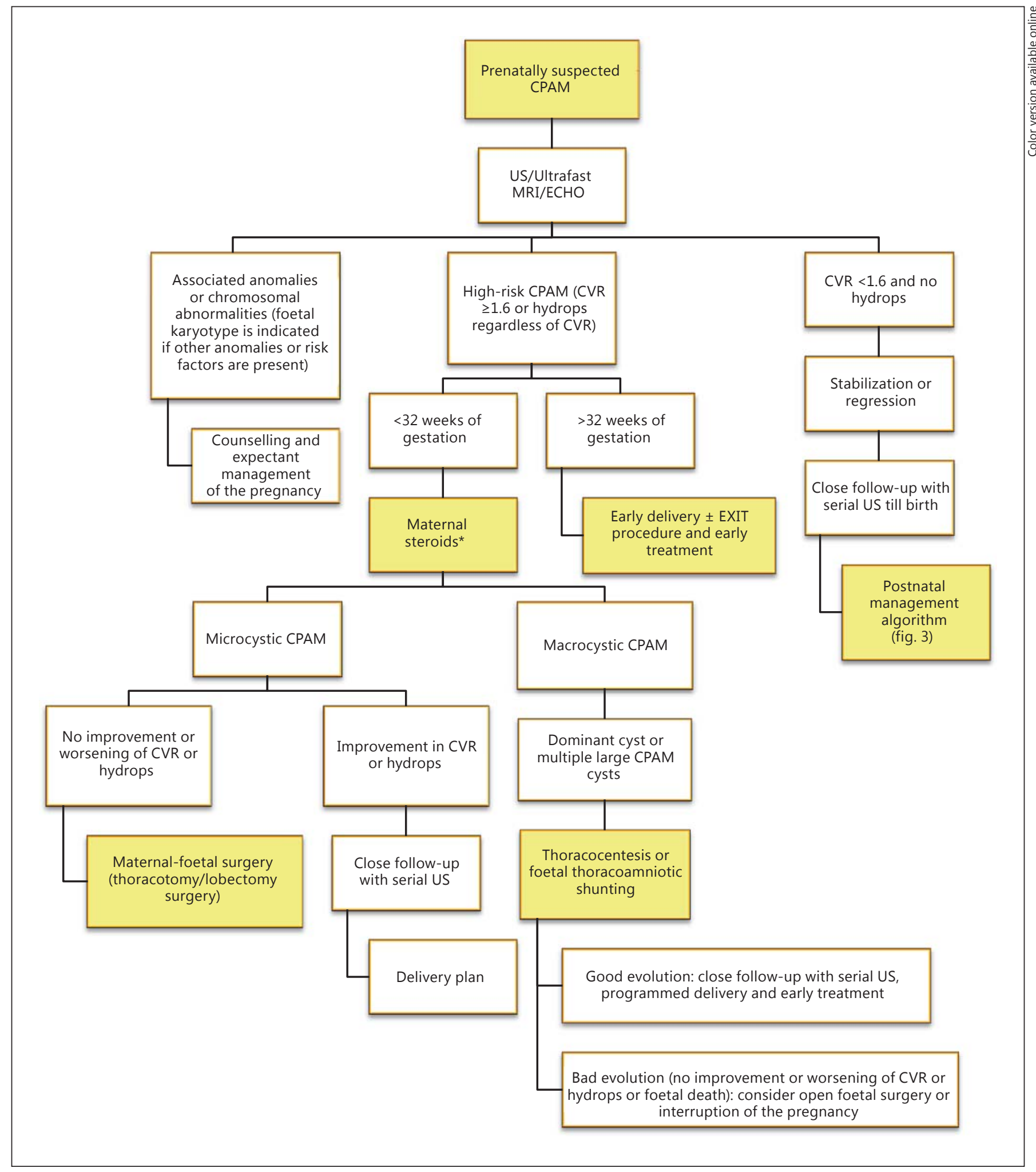

Fig. 1. Prenatal management algorithm $[15,17,53,60,69,72] . \mathrm{ECHO}=$ Echocardiogram. ${ }^{*}$ Multiple courses of betamethasone may be an option. 
Fig. 2. Genes implicated in CPAM, PPB and BAC $[14,30-35,127,137-143]$. TTF1 = Thyroid transcription factor 1 ; PDGF-B = platelet-derived growth factor $\mathrm{B}$; FABP-7 = fatty acid-binding protein 7; GDNF = glial cell-derived neurotrophic factor; Shh = sonic hedgehog; FGFR2b = FGF receptor-2b; FHIT = fragile histidine triad; $\mathrm{Rb}=$ retinoblastoma protein; EGFR = epidermal growth factor receptor.

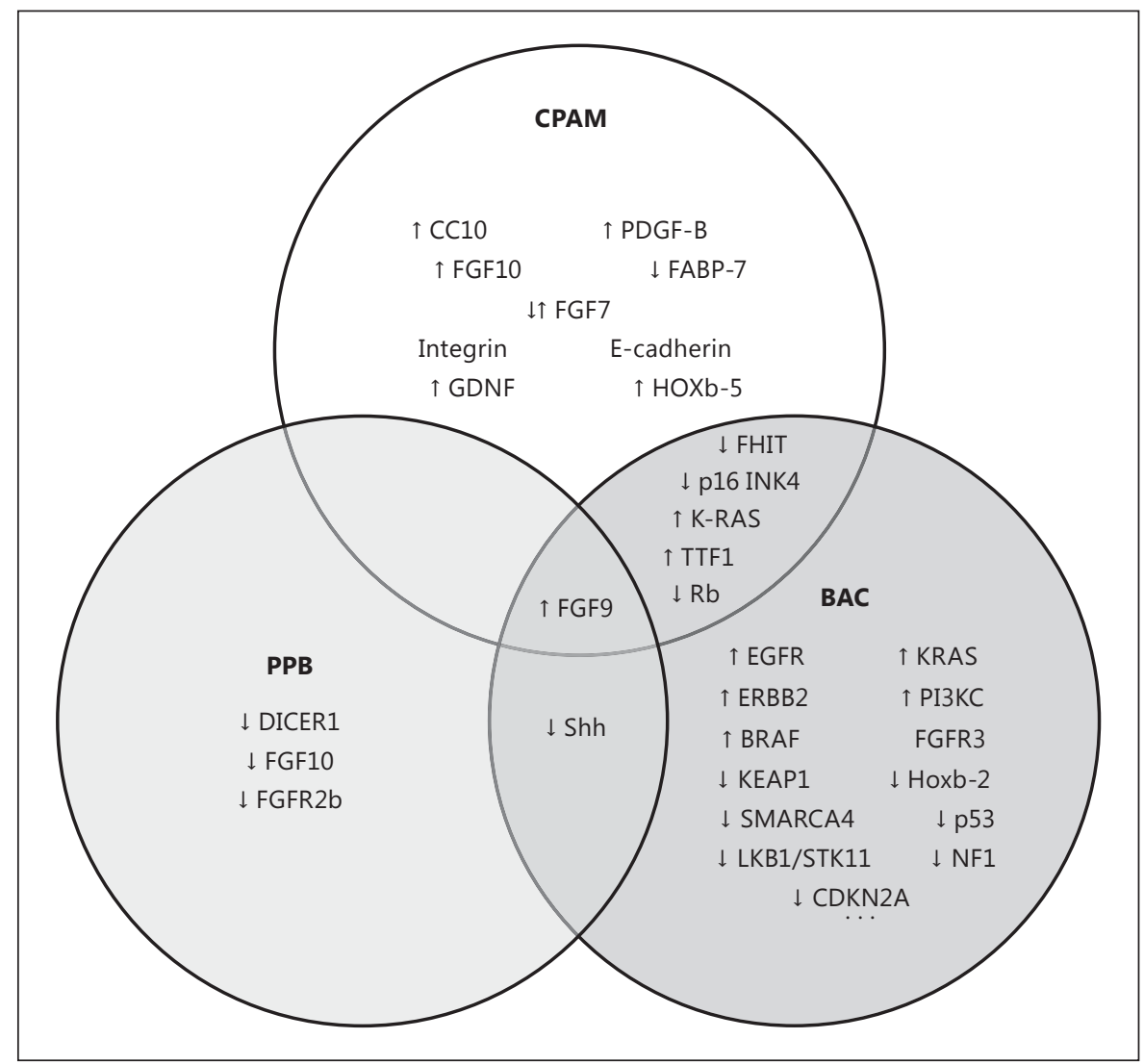

scopic approach can be the approach of choice for CPAM resection.

Lobectomy versus Parenchyma-Sparing Resection

Lobectomy appears to be the best treatment to avoid recurrent pulmonary infection and neoplasia. It is agreed among many surgeons and pathologists that the limit between CPAM and normal parenchyma is impossible to determine [116-118]. Muller et al. [119] demonstrated that preoperative CT is not predictive of extension of the malformation. Therefore, adopting subtotal lobectomy or segmentectomy has the risk of leaving remnants of the CPAM lesion, based only on a CT scan [120]. If the option is surgery, it is necessary to remove all abnormal tissue in order to avoid later infection or malignancy. However, a prospective study will be required to compare the longterm outcome of patients submitted to lobectomy or parenchyma-sparing resection (PSR) in terms of infection risk and neoplasia development. Some authors propose that PSR should be reserved for patients with bilobar or bilateral disease, as PSR is technically feasible and safe, with low postoperative complications $[119,121,122]$.
Table 2. Cases of malignant transformation associated with CPAM $[4,118,124,145-155]$

\begin{tabular}{llll}
\hline & \multicolumn{3}{l}{ CPAM type } \\
\cline { 2 - 4 } & unspecified $^{1}$ & type I & type IV \\
\hline $\begin{array}{l}\text { Bronchioloalveolar carcinoma } \\
\text { Mesenchymal malignancies }\end{array}$ & 2 & 18 & 0 \\
$\begin{array}{l}\text { Pulmonary blastoma } \\
\text { Rhabdomyosarcoma }\end{array}$ & 8 & 1 & 0 \\
Myxosarcoma & 7 & 1 & 0 \\
Embryonal rhabdomyosarcoma & 7 & 0 & 0 \\
Mixed mesenchymal sarcoma & 1 & 0 & 0 \\
Malignant mesenchymoma & 1 & 0 & 0 \\
PPB & 11 & 0 & 0 \\
\hline Total & 38 & 21 & 2 \\
\hline
\end{tabular}

${ }^{1}$ Unspecified cystic lesions or CPAM type. 


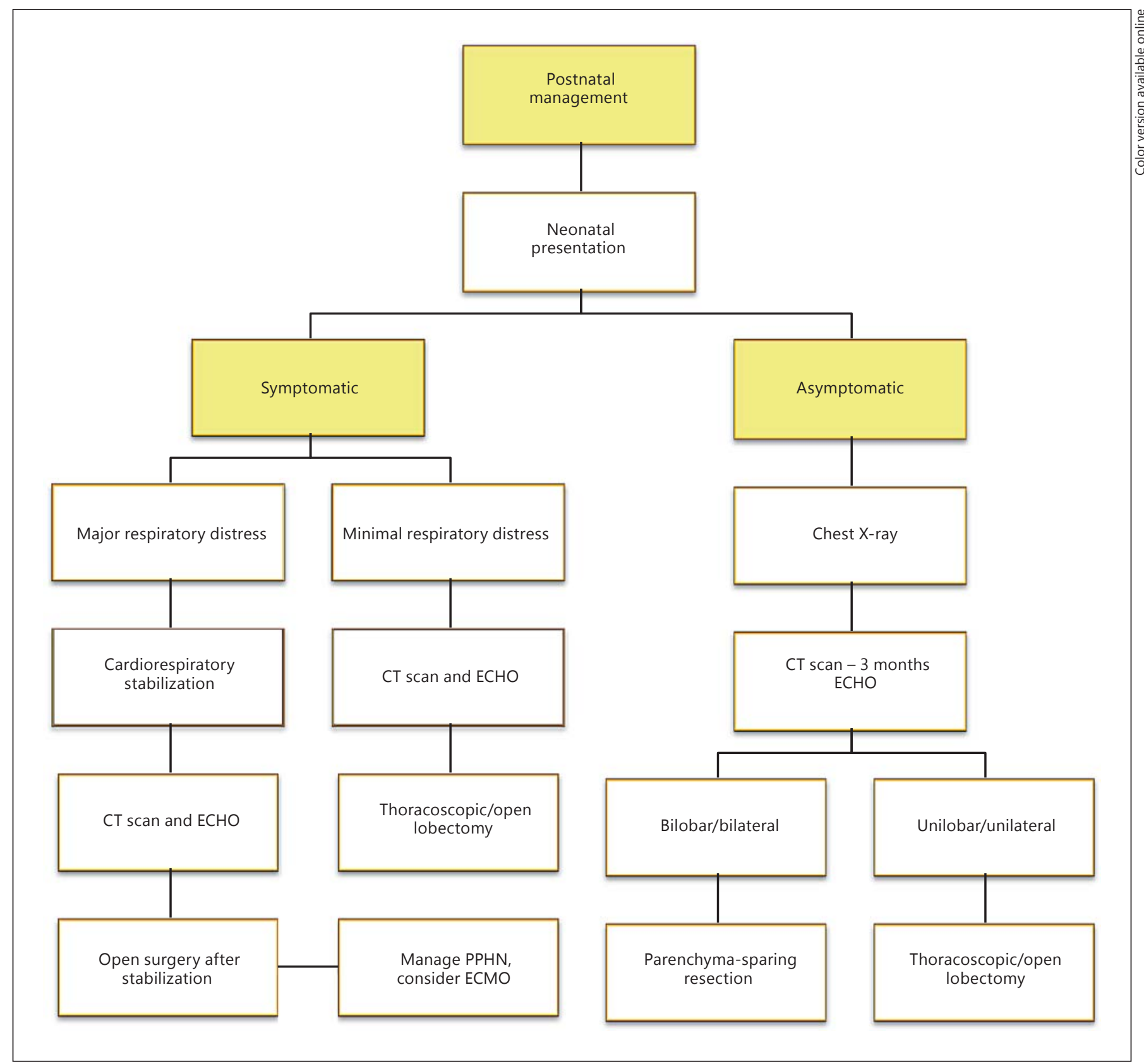

Fig. 3. Postnatal management algorithm $[3,116,118,119,144]$. ECHO = Echocardiogram; PPHN = persistent pulmonary hypertension of the newborn; ECMO = extracorporeal membrane oxygenation.

\section{Cancer Risk}

Although lung cancer associated with CPAM is rare, an increasing number of cases are being reported (table 2). A large review of childhood lung neoplasms demonstrated an association of $8.6 \%$ between malignant tumours and CPAMs [114]. A clear link between CPAM and lung cancer is missing, but some molecular pathways are shared between CPAMs and the two most frequent lung cancers associated to CPAM (fig. 2).

Pleuropulmonary blastoma (PPB) is a dysembryonic malignant sarcoma [104]. Since PPB is a recently recognised entity, many neoplasms previously reported as sarcomas or rhabdomyosarcomas might represent unrecognised PPBs (table 2) [8]. PPBs are classified into 
three types based on gross pathologic morphology, and on their radiographic and microscopic characteristics $[104,123]$. Type I PPB consists of a cystic lesion, clinically and radiologically indistinguishable from CPAM $[104,123]$. Type I PPB may also regress and persist without malignant potential, termed type Ir (regressed). In type II PPB, there are cystic lesion-thickened walls or septa, solid mural nodules and larger tumour excrescences $[104,123]$. Type III PPB is a solid high-grade sarcoma [104, 123]. A growing number of mesenchymal malignancies associated with CPAM have been reported, but the relation between PPB and CPAM is not obvious (table 2) [4, 104]. PPB affects mostly young children, including neonates, and is diagnosed at approximately 10 months of age for type I PPB. Most cases appear before the age of 6 years $[96,123,124]$. As in PPB and rhabdomyosarcomas, type II CPAM occasionally exhibits skeletal muscle differentiation [96]. The clinical similarity between the two lesions raises the hypothesis that PPB can develop within a CPAM $[96,107]$. In contrast, different PPB types may represent different stages of the same malignant process since recurrences of type I are usually type II or III PPB, and cysts could be a form of PPB rather than a CPAM [123, 125]. Early surgical resection may be advantageous by removing potential malignant tissue, since it is impossible to distinguish CPAM from type I PPB $[96,104,126]$. However, prophylactic resection may not prevent the development of $\mathrm{PPB}$, as there is a case of PPB after resections for bilateral CPAM [118].

CPAM-associated bronchioloalveolar carcinoma (BAC) has been reported, with all the documented cases occurring in patients with CPAM type I (table 2). Unlike $\mathrm{PPB}$, there is a more clear connection between CPAM and $\mathrm{BAC}$ [4]. CPAM type I is thought to be a precursor lesion to BAC [127]. Clusters of mucogenic cells are present in $35-50 \%$ of type I CPAMs [19]. Atypical adenomatous hyperplasia, atypical goblet cell hyperplasia and chromosomal aberrations have been described in CPAMs type I, supporting their eventual preneoplastic status [126, 128130]. Mucinous cells within CPAM type I produce gastric mucins similar to those found in BAC and have an increased frequency of KRAS mutations as well as a loss of heterozygosity at the tumour suppressor genes FHIT, p16INK4 and $R b$ [127]. The concept of malignant progression from type I CPAM to atypical goblet cell hyperplasia, or atypical adenomatous hyperplasia to BAC, has been supported by reports in which all the stages are present [131].

Prenatal and Postnatal Management of CPAM
Postnatal Management Algorithm

A postnatal management algorithm based on the early surgical treatment of asymptomatic patients has been proposed (fig. 3).

\section{Conclusion}

As knowledge about pathogenesis and the natural history of CPAM increases, the pre- and postnatal management of this condition will evolve and improve. Controversy still exists regarding the management and the treatment of asymptomatic patients. The prevention of infection and cancer, the improved restoration of lung volume and fewer complications might favour elective early surgery. The involvement of a multidisciplinary team in the management of these patients is of utmost importance to outline the adequate therapeutic algorithm.

\section{Future Perspectives}

Advances in genomic medicine have been applied in many fields of neonatal care and will certainly provide a new array of diagnostic and therapeutic tools [132-135]. Investigations have been performed on human lung cancer, but limited information is available about metabolic perturbations arising in situ from CPAM [133]. Pelizzo et al. [136] suggest that CPAMs have different metabolomic profiles that can be useful for early diagnosis, allowing planned treatment and prognosis during pregnancy. Further investigation of the regulation of these metabolic traits should be done in order to gain a better understanding of the phenotype of foetal lung lesions, specifically in CPAM.

References

Neonatology 2016;110:101-115

1 Stocker JT, Madewell JE, Drake RM: Congenital cystic adenomatoid malformation of the lung: classification and morphologic spectrum. Hum Pathol 1977;8:155-171.

2 Adzick NS, Harrison MR, Glick PL, Golbus MS, Anderson RL, Mahony BS, et al: Fetal cystic adenomatoid malformation: prenatal diagnosis and natural history. J Pediatr Surg 1985;20:483-488.

3 Ben-Ishay O, Nicksa GA, Wilson JM, Buchmiller TL: Management of giant congenital pulmonary airway malformations requiring pneumonectomy. Ann Thorac Surg 2012;94: 1073-1078. 
4 Laberge JM, Puligandla P, Flageole H: Asymptomatic congenital lung malformations. Semin Pediatr Surg 2005;14:16-33.

5 Cass DL, Olutoye OO, Cassady CI, Moise KJ, Johnson A, Papanna R, et al: Prenatal diagnosis and outcome of fetal lung masses. J Pediatr Surg 2011;46:292-298.

6 Kotecha S, Barbato A, Bush A, Claus F, Davenport M, Delacourt C, et al: Antenatal and postnatal management of congenital cystic adenomatoid malformation. Paediatr Respir Rev 2012;13:162-170.

7 Nagata K, Masumoto K, Tesiba R, Esumi G, Tsukimori K, Norio W, et al: Outcome and treatment in an antenatally diagnosed congenital cystic adenomatoid malformation of the lung. Pediatr Surg Int 2009;25:753-757.

8 Langston C: New concepts in the pathology of congenital lung malformations. Semin Pediatr Surg 2003;12:17-37.

9 Cass DL, Crombleholme TM, Howell LJ, Stafford PW, Ruchelli ED, Adzick NS: Cystic lung lesions with systemic arterial blood supply: a hybrid of congenital cystic adenomatoid malformation and bronchopulmonary sequestration. J Pediatr Surg 1997;32:986-990.

10 Ch'In KY, Tang MY: Congenital adenomatoid malformation of one lobe of a lung with general anasarca. Arch Pathol 1949;48:221229.

11 Stocker JT: Congenital and developmental diseases; in Dail DH, Hammar SP (eds): Pulmonary Pathology, ed 3. New York, Springer, 2008, pp 154-180.

12 Newman B: Congenital bronchopulmonary foregut malformations: concepts and controversies. Pediatr Radiol 2006;36:773-791.

13 Morotti RA, Cangiarella J, Gutierrez MC, Jagirdar J, Askin F, Singh G, et al: Congenital cystic adenomatoid malformation of the lung (CCAM): evaluation of the cellular components. Hum Pathol 1999;30:618-625.

14 Morotti RA, Gutierrez MC, Askin F, Profitt SA, Wert SE, Whitsett JA, et al: Expression of thyroid transcription factor- 1 in congenital cystic adenomatoid malformation of the lung. Pediatr Dev Pathol 2000;3:455-461.

15 Adzick NS, Harrison MR, Crombleholme TM, Flake AW, Howell LJ: Fetal lung lesions: management and outcome. Am J Obstet Gynecol 1998;179:884-889.

16 Correia-Pinto J, Gonzaga S, Huang Y, Rottier R: Congenital lung lesions - underlying molecular mechanisms. Semin Pediatr Surg 2010;19:171-179.

17 Wilson RD, Hedrick HL, Liechty KW, Flake AW, Johnson MP, Bebbington M, et al: Cystic adenomatoid malformation of the lung: review of genetics, prenatal diagnosis, and in utero treatment. Am J Med Genet A 2006;140: 151-155.

18 Bush A: Congenital lung disease: a plea for clear thinking and clear nomenclature. Pediatr Pulmonol 2001;32:328-337.

19 Ramos SG, Barbosa GH, Tavora FR, Jeudy J, Torres LA, Tone LG, et al: Bronchioloalveolar carcinoma arising in a congenital pulmonary airway malformation in a child: case report with an update of this association. J Pediatr Surg 2007;42:E1-E4.

20 Williams HJ, Johnson KJ: Imaging of congenital cystic lung lesions. Paediatr Respir Rev 2002;3:120-127.

21 Vu L, Tsao K, Lee H, Nobuhara K, Farmer D, Harrison M, et al: Characteristics of congenital cystic adenomatoid malformations associated with nonimmune hydrops and outcome. J Pediatr Surg 2007;42:1351-1356.

22 Rosado-de-Christenson ML, Stocker JT: Congenital cystic adenomatoid malformation. Radiographics 1991;11:865-886.

23 Raychaudhuri P, Pasupati A, James A, Whitehead B, Kumar R: Prospective study of antenatally diagnosed congenital cystic adenomatoid malformations. Pediatr Surg Int 2011;27: 1159-1164.

24 van Koningsbruggen S, Ahrens F, Brockmann M, Michalk D, Rietschel E: Congenital cystic adenomatoid malformation type 4 . Pediatr Pulmonol 2001;32:471-475.

25 Joshi S, Kotecha S: Lung growth and development. Early Hum Dev 2007;83:789-794.

26 Groenman F, Unger S, Post M: The molecular basis for abnormal human lung development. Biol Neonate 2005;87:164-177.

27 Perl AK, Whitsett JA: Molecular mechanisms controlling lung morphogenesis. Clin Genet 1999;56:14-27.

28 Cass DL, Quinn TM, Yang EY, Liechty KW, Crombleholme TM, Flake AW, et al: Increased cell proliferation and decreased apoptosis characterize congenital cystic adenomatoid malformation of the lung. J Pediatr Surg 1998;33:1043-1046; discussion 1047.

29 Simonet WS, DeRose ML, Bucay N, Nguyen HQ, Wert SE, Zhou L, et al: Pulmonary malformation in transgenic mice expressing human keratinocyte growth factor in the lung. Proc Natl Acad Sci USA 1995;92:1246112465.

30 Liechty KW, Crombleholme TM, Quinn TM, Cass DL, Flake AW, Adzick NS: Elevated platelet-derived growth factor-B in congenital cystic adenomatoid malformations requiring fetal resection. J Pediatr Surg 1999;34: 805-809; discussion 809-810.

31 Fromont-Hankard G, Philippe-Chomette P, Delezoide AL, Nessmann C, Aigrain Y, Peuchmaur M: Glial cell-derived neurotrophic factor expression in normal human lung and congenital cystic adenomatoid malformation. Arch Pathol Lab Med 2002;126:432-436.

32 Volpe MV, Pham L, Lessin M, Ralston SJ, Bhan I, Cutz E, et al: Expression of Hoxb-5 during human lung development and in congenital lung malformations. Birth Defects Res A Clin Mol Teratol 2003;67:550-556.

33 Jancelewicz T, Nobuhara K, Hawgood S: Laser microdissection allows detection of abnormal gene expression in cystic adenomatoid malformation of the lung. J Pediatr Surg 2008;43:1044-1051.

34 Wagner AJ, Stumbaugh A, Tigue Z, Edmondson J, Paquet AC, Farmer DL, et al: Genetic analysis of congenital cystic adenomatoid malformation reveals a novel pulmonary gene: fatty acid binding protein-7 (brain type). Pediatr Res 2008;64:11-16.

35 Volpe MV, Chung E, Ulm JP, Gilchrist BF, Ralston S, Wang KT, et al: Aberrant cell adhesion molecule expression in human bronchopulmonary sequestration and congenital cystic adenomatoid malformation. Am J Physiol Lung Cell Mol Physiol 2009; 297:L143-L152.

36 Gontan C, de Munck A, Vermeij M, Grosveld F, Tibboel D, Rottier R: Sox2 is important for two crucial processes in lung development: branching morphogenesis and epithelial cell differentiation. Dev Biol 2008; 317:296-309.

37 Schilders K, Ochieng JK, van de Ven CP, Gon$\tan$ C, Tibboel D, Rottier RJ: Role of SOX2 in foregut development in relation to congenital abnormalities. World J Med Genet 2014;4: 94-104.

38 Gonzaga S, Henriques-Coelho T, Davey M, Zoltick PW, Leite-Moreira AF, Correia-Pinto $\mathrm{J}$, et al: Cystic adenomatoid malformations are induced by localized FGF10 overexpression in fetal rat lung. Am J Respir Cell Mol Biol 2008;39:346-355.

39 Griffin N, Devaraj A, Goldstraw P, Bush A, Nicholson AG, Padley S: CT and histopathological correlation of congenital cystic pulmonary lesions: a common pathogenesis? Clin Radiol 2008;63:995-1005.

40 Breysem L, Bosmans H, Dymarkowski S, Schoubroeck DV, Witters I, Deprest J, et al: The value of fast MR imaging as an adjunct to ultrasound in prenatal diagnosis. Eur Radiol 2003;13:1538-1548.

41 Tsai AY, Liechty KW, Hedrick HL, Bebbington M, Wilson RD, Johnson MP, et al: Outcomes after postnatal resection of prenatally diagnosed asymptomatic cystic lung lesions. J Pediatr Surg 2008;43:513-517.

42 Farrugia MK, Raza SA, Gould S, Lakhoo K Congenital lung lesions: classification and concordance of radiological appearance and surgical pathology. Pediatr Surg Int 2008;24: 987-991.

43 Makhija Z, Moir CR, Allen MS, Cassivi SD, Deschamps C, Nichols F 3rd, et al: Surgical management of congenital cystic lung malformations in older patients. Ann Thorac Surg 2011;91:1568-1573; discussion 1573.

44 Marshall KW, Blane CE, Teitelbaum DH, van Leeuwen K: Congenital cystic adenomatoid malformation: impact of prenatal diagnosis and changing strategies in the treatment of the asymptomatic patient. AJR Am J Roentgenol 2000;175:1551-1554.

45 Alamo L, Gudinchet F, Reinberg O, Vial Y, Francini K, Osterheld MC, et al: Prenatal diagnosis of congenital lung malformations. Pediatr Radiol 2012;42:273-283.

46 Kline-Fath B, Bitters C: Prenatal imaging of fetal lung lesions: magnetic resonance imaging complements ultrasound. J Radiol Nurs 2010;29:3-9. 
47 Epelman M, Kreiger PA, Servaes S, Victoria T, Hellinger JC: Current imaging of prenatally diagnosed congenital lung lesions. Semin Ultrasound CT MR 2010;31:141-157.

48 Liu YP, Chen CP, Shih SL, Chen YF, Yang FS, Chen SC: Fetal cystic lung lesions: evaluation with magnetic resonance imaging. Pediatr Pulmonol 2010;45:592-600.

49 Shanmugam G, MacArthur K, Pollock JC: Congenital lung malformations - antenatal and postnatal evaluation and management. Eur J Cardiothorac Surg 2005;27:45-52.

50 Sauvat F, Michel JL, Benachi A, Emond S, Revillon Y: Management of asymptomatic neonatal cystic adenomatoid malformations. J Pediatr Surg 2003;38:548-552.

51 Cavoretto P, Molina F, Poggi S, Davenport M, Nicolaides KH: Prenatal diagnosis and outcome of echogenic fetal lung lesions. Ultrasound Obstet Gynecol 2008;32:769-783.

52 Crombleholme TM, Coleman B, Hedrick H, Liechty K, Howell L, Flake AW, et al: Cystic adenomatoid malformation volume ratio predicts outcome in prenatally diagnosed cystic adenomatoid malformation of the lung. J Pediatr Surg 2002;37:331-338.

53 Azizkhan RG, Crombleholme TM: Congenital cystic lung disease: contemporary antenatal and postnatal management. Pediatr Surg Int 2008;24:643-657.

54 Eber E: Antenatal diagnosis of congenital thoracic malformations: early surgery, late surgery, or no surgery? Semin Respir Crit Care Med 2007;28:355-366.

55 Cass DL, Olutoye OO, Ayres NA, Moise KJ Jr, Altman CA, Johnson A, et al: Defining hydrops and indications for open fetal surgery for fetuses with lung masses and vascular tumors. J Pediatr Surg 2012;47:40-45.

56 Ankermann T, Oppermann HC, Engler S, Leuschner I, von Kaisenberg CS: Congenital masses of the lung, cystic adenomatoid malformation versus congenital lobar emphysema. J Ultrasound Med 2004;23:1379-1384.

57 Laje P, Liechty KW: Postnatal management and outcome of prenatally diagnosed lung lesions. Prenat Diagn 2008;28:612-618.

58 Bunduki V, Ruano R, da Silva MM, Miguelez J, Miyadahira S, Maksoud JG, et al: Prognostic factors associated with congenital cystic adenomatoid malformation of the lung. Prenat Diagn 2000;20:459-464.

59 Blau H, Barak A, Karmazyn B, Mussaffi H, Ben Ari J, Schoenfeld T, et al: Postnatal management of resolving fetal lung lesions. Pediatrics 2002;109:105-108.

60 Bush A, Hogg J, Chitty LS: Cystic lung lesions - prenatal diagnosis and management. Prenat Diagn 2008;28:604-611.

61 Chowdhury MM, Chakraborty S: Imaging of congenital lung malformations. Semin Pediatr Surg 2015;24:168-175.

62 Kongstad T, Buchvald F, Brenoe J, Petersen BL, Tabor A, Nielsen KG: Radiology, histology and short-term outcome of asymptomatic congenital thoracic malformations. Acta Paediatr 2012;101:155-158.
63 Witlox RS, Lopriore E, Oepkes D: Prenatal interventions for fetal lung lesions. Prenat Diagn 2011;31:628-636.

64 Knox EM, Kilby MD, Martin WL, Khan KS: In-utero pulmonary drainage in the management of primary hydrothorax and congenital cystic lung lesion: a systematic review. Ultrasound Obstet Gynecol 2006;28:726-734.

65 Loh KC, Jelin E, Hirose S, Feldstein V, Goldstein R, Lee H: Microcystic congenital pulmonary airway malformation with hydrops fetalis: steroids vs open fetal resection. J Pediatr Surg 2012;47:36-39.

66 Tsao K, Hawgood S, Vu L, Hirose S, Sydorak $\mathrm{R}$, Albanese CT, et al: Resolution of hydrops fetalis in congenital cystic adenomatoid malformation after prenatal steroid therapy. J Pediatr Surg 2003;38:508-510.

67 Curran PF, Jelin EB, Rand L, Hirose S, Feldstein VA, Goldstein RB, et al: Prenatal steroids for microcystic congenital cystic adenomatoid malformations. J Pediatr Surg 2010; 45:145-150

68 Adzick NS: Management of fetal lung lesions. Clin Perinatol 2003;30:481-492.

69 Adzick NS: Open fetal surgery for life-threatening fetal anomalies. Semin Fetal Neonatal Med 2010;15:1-8.

70 Higby K, Melendez BA, Heiman HS: Spontaneous resolution of nonimmune hydrops in a fetus with a cystic adenomatoid malformation. J Perinatol 1998;18:308-310.

71 Peranteau WH, Wilson RD, Liechty KW, Johnson MP, Bebbington MW, Hedrick HL, et al: Effect of maternal betamethasone administration on prenatal congenital cystic adenomatoid malformation growth and fetal survival. Fetal Diagn Ther 2007;22:365-371.

72 Morris LM, Lim FY, Livingston JC, Polzin WJ, Crombleholme TM: High-risk fetal congenital pulmonary airway malformations have a variable response to steroids. J Pediatr Surg 2009;44:60-65.

73 Derderian S, Coleman A, Jeanty C, Lim F, Shaaban A, Farrell J, et al: Favorable outcomes in high-risk congenital pulmonary airway malformations treated with multiple courses of maternal betamethasone. J Pediatr Surg 2015;50:515-518

74 San Feliciano L, Remesal A, Isidoro-García M, Ludeña D: Dexamethasone and betamethasone for prenatal lung maturation: differences in vascular endothelial growth factor expression and alveolarization in rats. Neonatology 2011;100:105-110.

75 Remesal A, San Feliciano L, Isidoro-García M, Ludeña D: Effects of antenatal betamethasone and dexamethasone on the lung expression of vascular endothelial growth factor and alveolarization in newborn rats exposed to acute hypoxia and recovered in normoxia or hyperoxia. Neonatology 2010; 98:313-320.

76 Schrey S, Kelly EN, Langer JC, Davies GA, Windrim R, Seaward PG, et al: Fetal thoracoamniotic shunting for large macrocystic congenital cystic adenomatoid malforma- tions of the lung. Ultrasound Obstet Gynecol 2012;39:515-520.

77 Wilson RD: In utero therapy for fetal thoracic abnormalities. Prenat Diagn 2008;28:619-625.

78 Wilson RD, Baxter JK, Johnson MP, King M, Kasperski S, Crombleholme TM, et al: Thoracoamniotic shunts: fetal treatment of pleural effusions and congenital cystic adenomatoid malformations. Fetal Diagn Ther 2004;19: 413-420.

79 Merchant AM, Peranteau W, Wilson RD, Johnson MP, Bebbington MW, Hedrick HL, et al: Postnatal chest wall deformities after fetal thoracoamniotic shunting for congenital cystic adenomatoid malformation. Fetal Diagn Ther 2007;22:435-439.

80 Matsuoka K, Hayashi S, Urano F, Zhu LJ, Okita H, Sago H, et al: Squamous metaplasia in the cyst epithelium of type 1 congenital pulmonary airway malformation after thoracoamniotic shunt placement. Hum Pathol 2012;43:1413-1717.

81 Liechty KW, Crombleholme TM: Management of fetal airway obstruction. Semin Perinatol 1999;23:496-506.

82 Bouchard S, Johnson MP, Flake AW, Howell LJ, Myers LB, Adzick NS, et al: The EXIT procedure: experience and outcome in 31 cases. J Pediatr Surg 2002;37:418-426.

83 Hedrick HL: Ex utero intrapartum therapy. Semin Pediatr Surg 2003;12:190-195.

84 Crombleholme T, Albanese C: The fetus with airway obstruction; in: The Unborn Patient: The Art and Science of Fetal Therapy. Philadelphia, Saunders, 2001, pp 357-372.

85 Harrison MR, Adzick NS, Flake AW, VanderWall KJ, Bealer JF, Howell LJ, et al: Correction of congenital diaphragmatic hernia in utero VIII: response of the hypoplastic lung to tracheal occlusion. J Pediatr Surg 1996;31:1339_ 1348.

86 Hirose S, Harrison MR: The ex utero intrapartum treatment (EXIT) procedure. Semin Neonatol 2003;8:207-214.

87 Marwan A, Crombleholme TM: The EXIT procedure: principles, pitfalls, and progress. Semin Pediatr Surg 2006;15:107-115.

88 Liechty KW: Ex-utero intrapartum therapy. Semin Fetal Neonatal Med 2010;15:34-39.

89 Hedrick HL, Flake AW, Crombleholme TM, Howell LJ, Johnson MP, Wilson RD, et al: The ex utero intrapartum therapy procedure for high-risk fetal lung lesions. J Pediatr Surg 2005;40:1038-1043; discussion 1044.

90 Cass DL, Olutoye OO, Cassady CI, Zamora IJ, Ivey RT, Ayres NA, et al: EXIT-to-resection for fetuses with large lung masses and persistent mediastinal compression near birth. J Pediatr Surg 2013;48:138-144.

91 Mann S, Wilson RD, Bebbington MW, Adzick NS, Johnson MP: Antenatal diagnosis and management of congenital cystic adenomatoid malformation. Semin Fetal Neonatal Med 2007;12:477-481.

92 Khalek N, Johnson MP: Management of prenatally diagnosed lung lesions. Semin Pediatr Surg 2013;22:24-29. 
93 Kotecha S, Barbato A, Bush A, Claus F, Davenport M, Delacourt C, et al: Antenatal and postnatal management of congenital cystic adenomatoid malformation. Paediatr Respir Rev 2012;13:162-171.

94 Lo AY, Jones S: Lack of consensus among Canadian pediatric surgeons regarding the management of congenital cystic adenomatoid malformation of the lung. J Pediatr Surg 2008;43:797-799.

95 Calvert JK, Lakhoo K: Antenatally suspected congenital cystic adenomatoid malformation of the lung: postnatal investigation and timing of surgery. J Pediatr Surg 2007;42: 411-414.

96 Priest JR, McDermott MB, Bhatia S, Watterson J, Manivel JC, Dehner LP: Pleuropulmonary blastoma: a clinicopathologic study of 50 cases. Cancer 1997;80:147-161.

97 van Leeuwen K, Teitelbaum DH, Hirschl RB, Austin E, Adelman SH, Polley TZ, et al: Prenatal diagnosis of congenital cystic adenomatoid malformation and its postnatal presentation, surgical indications, and natural history. J Pediatr Surg 1999;34:794-798; discussion 798-799.

98 Aspirot A, Puligandla PS, Bouchard S, Su W, Flageole H, Laberge JM: A contemporary evaluation of surgical outcome in neonates and infants undergoing lung resection. J Pediatr Surg 2008;43:508-512.

99 Truitt AK, Carr SR, Cassese J, Kurkchubasche AG, Tracy TF Jr, Luks FI: Perinatal management of congenital cystic lung lesions in the age of minimally invasive surgery. J Pediatr Surg 2006;41:893-896.

100 Stanton M, Njere I, Ade-Ajayi N, Patel S, Davenport M: Systematic review and metaanalysis of the postnatal management of congenital cystic lung lesions. J Pediatr Surg 2009;44:1027-1033.

101 Bagolan P, Nahom A, Giorlandino C, Trucchi A, Bilancioni E, Inserra A, et al: Cystic adenomatoid malformation of the lung: clinical evolution and management. Eur J Pediatr 1999;158:879-882.

102 Dehner LP: Pleuropulmonary blastoma is THE pulmonary blastoma of childhood. Semin Diagnostic Pathol 1994;11:144-151.

103 Aziz D, Langer JC, Tuuha SE, Ryan G, Ein SH, Kim PC: Perinatally diagnosed asymptomatic congenital cystic adenomatoid malformation: to resect or not? J Pediatr Surg 2004;39:329-334; discussion 329-334.

104 Priest JR, Williams GM, Hill DA, Dehner LP, Jaffe A: Pulmonary cysts in early childhood and the risk of malignancy. Pediatr Pulmonol 2009;44:14-30.

105 Komori K, Kamagata S, Hirobe S, Toma M, Okumura K, Muto M, et al: Radionuclide imaging study of long-term pulmonary function after lobectomy in children with congenital cystic lung disease. J Pediatr Surg 2009;44:2096-2100.

106 Zach MS, Eber E: Adult outcome of congenital lower respiratory tract malformations. Thorax 2001;56:65-72.
107 Hill DA, Dehner LP: A cautionary note about congenital cystic adenomatoid malformation (CCAM) type 4. Am J Surg Pathol 2004;28:554-555; author reply 555.

108 Parikh D, Samuel M: Congenital cystic lung lesions: is surgical resection essential? Pediatr Pulmonol 2005;40:533-537.

109 Thurlbeck WM: Postnatal human lung growth. Thorax 1982;37:564-571.

110 Werner HA, Pirie GE, Nadel HR, Fleisher AG, LeBlanc JG: Lung volumes, mechanics, and perfusion after pulmonary resection in infancy. J Thorac Cardiovasc Surg 1993;105: 737-742.

111 Burri PH: Structural aspects of postnatal lung development - alveolar formation and growth. Biol Neonate 2006;89:313-322.

112 Merkus PJ, ten Have-Opbroek AA, Quanjer PH: Human lung growth: a review. Pediatr Pulmonol 1996;21:383-397.

113 Keijzer R, Chiu PP, Ratjen F, Langer JC: Pulmonary function after early vs late lobectomy during childhood: a preliminary study. J Pediatr Surg 2009;44:893-895.

114 Hancock BJ, Di Lorenzo M, Youssef S, Yaz beck S, Marcotte JE, Collin PP: Childhood primary pulmonary neoplasms. J Pediatr Surg 1993;28:1133-1136.

115 Nasr A, Bass J: Thoracoscopic vs open resection of congenital lung lesions: a meta-analysis. J Pediatr Surg 2012;47:857-861.

116 Bratu I, Flageole H, Chen MF, Di Lorenzo M, Yazbeck S, Laberge JM: The multiple facets of pulmonary sequestration. J Pediatr Surg 2001;36:784-790.

117 Davenport M, Warne SA, Cacciaguerra S, Patel S, Greenough A, Nicolaides K: Current outcome of antenally diagnosed cystic lung disease. J Pediatr Surg 2004;39:549-556.

118 Papagiannopoulos KA, Sheppard M, Bush AP, Goldstraw P: Pleuropulmonary blastoma: is prophylactic resection of congenital lung cysts effective? Ann Thorac Surg 2001; 72:604-605.

119 Muller CO, Berrebi D, Kheniche A, Bonnard A: Is radical lobectomy required in congenital cystic adenomatoid malformation? J Pediatr Surg 2012;47:642-645.

120 Vu LT, Farmer DL, Nobuhara KK, Miniati $\mathrm{D}$, Lee $\mathrm{H}$ : Thoracoscopic versus open resection for congenital cystic adenomatoid malformations of the lung. J Pediatr Surg 2008; 43:35-39.

121 Khosa JK, Leong SL, Borzi PA: Congenital cystic adenomatoid malformation of the lung: indications and timing of surgery. Pediatr Surg Int 2004;20:505-508.

122 Kim HK, Choi YS, Kim K, Shim YM, Ku GW, Ahn KM, et al: Treatment of congenital cystic adenomatoid malformation: should lobectomy always be performed? Ann Thorac Surg 2008;86:249-253.

123 Schneider DT: Rare tumors in children and adolescents. Heidelberg, Springer, 2012.
124 Nasr A, Himidan S, Pastor AC, Taylor G, Kim PC: Is congenital cystic adenomatoid malformation a premalignant lesion for pleuropulmonary blastoma? J Pediatr Surg 2010;45:1086-1089.

125 Priest JR, Hill DA, Williams GM, Moertel CL, Messinger Y, Finkelstein MJ, et al: Type I pleuropulmonary blastoma: a report from the International Pleuropulmonary Blastoma Registry. J Clin Oncol 2006;24:4492-4498.

126 MacSweeney F, Papagiannopoulos K, Goldstraw P, Sheppard MN, Corrin B, Nicholson AG: An assessment of the expanded classification of congenital cystic adenomatoid malformations and their relationship to malignant transformation. Am J Surg Pathol 2003;27:1139-1146.

127 Lantuejoul S, Nicholson AG, Sartori G, Piolat C, Danel C, Brabencova E, et al: Mucinous cells in type 1 pulmonary congenital cystic adenomatoid malformation as mucinous bronchioloalveolar carcinoma precursors. Am J Surg Pathol 2007;31:961-969.

128 Ioachimescu OC, Mehta AC: From cystic pulmonary airway malformation, to bronchioloalveolar carcinoma and adenocarcinoma of the lung. Eur Respir J 2005;26: 1181-1187.

129 Stacher E, Ullmann R, Halbwedl I, GoggKammerer M, Boccon-Gibod L, Nicholson AG, et al: Atypical goblet cell hyperplasia in congenital cystic adenomatoid malformation as a possible preneoplasia for pulmonary adenocarcinoma in childhood: a genetic analysis. Hum Pathol 2004;35:565-570.

130 Mani H, Shilo K, Galvin JR, Stocker JT, Franks TJ: Spectrum of precursor and invasive neoplastic lesions in type 1 congenital pulmonary airway malformation: case report and review of the literature. Histopathology 2007;51:561-565.

131 Summers RJ, Shehata BM, Bleacher JC Stockwell C, Rapkin L: Mucinous adenocarcinoma of the lung in association with congenital pulmonary airway malformation. J Pediatr Surg 2010;45:2256-2259.

132 Hamvas A: Current technology in the diagnosis of developmentally related lung disorders. Neonatology 2012;101:353-359.

133 Mimmi MC, Ballico M, Nakib G, Calcaterra V, Peiro JL, Marotta M, et al: Altered metabolic profile in congenital lung lesions revealed by $1 \mathrm{H}$ nuclear magnetic resonance spectroscopy. ISRN Anal Chem 2014;2014: 391836.

134 Fanos V, van den Anker J, Noto A, Mussap M, Atzori L: Metabolomics in neonatology: fact or fiction? Semin Fetal Neonatal Med 2013;18:3-12.

135 Fanos V, Iacovidou N, Puddu M, Ottonello G, Noto A, Atzori L: Metabolomics in neonatal life. Early Hum Dev 2013;89:S7-S10.

136 Pelizzo G, Mimmi MC, Ballico M, Marotta M, Goruppi I, Peiro JL, et al: Congenital pulmonary malformations: metabolomic profile of lung phenotype in infants. J Matern Fetal Neonatal Med 2016;29:143-147. 
137 Lezmi G, Verkarre V, Khen-Dunlop N, Vibhushan S, Hadchouel A, Rambaud C, et al: FGF10 Signaling differences between type I pleuropulmonary blastoma and congenital cystic adenomatoid malformation. Orphanet J Rare Dis 2013;8:130.

138 Yin Y, Castro AM, Hoekstra M, Yan TJ, Kanakamedala AC, Dehner LP, et al: Fibroblast growth factor 9 regulation by microRNAs controls lung development and links DICER1 loss to the pathogenesis of pleuropulmonary blastoma. PLoS Genet 2015; 11:e1005242.

139 Esteban E, Majem M, Aguillo MM, Banaclocha NM, Dómine M, Aldaravi LG, et al: Prevalence of EGFR mutations in newly diagnosed locally advanced or metastatic nonsmall cell lung cancer Spanish patients and its association with histological subtypes and clinical features: the Spanish REASON study. Cancer Epidemiol 2015;39:291-297.

140 Cass DL, Quinn TM, Yang EY, Liechty KW, Crombleholme TM, Flake AW, et al: Increased cell proliferation and decreased apoptosis characterize congenital cystic adenomatoid malformation of the lung. J Pediatr Surg 1998;33:1043-1047.

141 Hwang J, Kang MH, Yoo YA, Quan YH, Kim HK, Oh SC, et al: The effects of sonic hedgehog signaling pathway components on nonsmall-cell lung cancer progression and clinical outcome. World J Surg Oncol 2014;12: 268.
142 Sousa V, Bastos B, Silva M, Alarcao AM, Carvalho L: Bronchial-pulmonary adenocarcinoma subtyping relates with different molecular pathways. Rev Port Pneumol 2015;21:259-270.

143 Yin Y, Betsuyaku T, Garbow JR, Miao J, Govindan R, Ornitz DM: Rapid induction of lung adenocarcinoma by fibroblast growth factor 9 signaling through FGF receptor 3. Cancer Res 2013;73:5730-5741.

144 Parikh DH, Rasiah SV: Congenital lung lesions: postnatal management and outcome. Semin Pediatr Surg 2015;24:160-167.

145 West D, Nicholson AG, Colquhoun I, Pollock J: Bronchioloalveolar carcinoma in congenital cystic adenomatoid malformation of lung. Ann Thorac Surg 2007;83:687689.

146 Endo T, Inoue M, Watanabe N, Tanaka I, Futonaka H, Takemura T: Two operative cases of pulmonary blastoma (in Japanese). Kyobu Geka 1982;35:219-224.

147 Stephanopoulos C, Catsaras H: Myxosarcoma complicating a cystic hamartoma of the lung. Thorax 1963;18:144-145.

148 Pai S, Eng HL, Lee SY, Hsiao CC, Huang WT, Huang SC: Rhabdomyosarcoma arising within congenital cystic adenomatoid malformation. Pediatr Blood Cancer 2005; 45:841-845.

149 Doladzas T, Arvelakis A, Karavokyros IG, Gougoudi E, Pikoulis E, Patsouris E, et al: Primary rhabdomyosarcoma of the lung arising over cystic pulmonary adenomatoid malformation. Pediatr Hematol Oncol 2005; 22:525-529.
150 Nur S, Badr R, Sandoval C, Brudniki A, Yeh A: Syndromic presentation of a pleuropulmonary blastoma associated with congenital cystic adenomatoid malformation: a case report. J Pediatr Surg 2007;42:1772-1775.

151 Gutweiler JR, Labelle J, Suh MY, Misra MV, Ahmed M, Lee EY, et al: A familial case of pleuropulmonary blastoma. Eur J Pediatr Surgery 2008;18:192-194.

152 Ishida M, Igarashi T, Teramoto K, Hanaoka J, Iwai M, Yoshida K, et al: Mucinous bronchioloalveolar carcinoma with K-ras mutation arising in type 1 congenital cystic adenomatoid malformation: a case report with review of the literature. Int J Clin Exp Pathol 2013;6:2597-2602.

153 Kim MY, Kang CH, Park SH: Multifocal synchronous mucinous adenocarcinomas arising in congenital pulmonary airway malformation: a case report with molecular study. Histopathology 2014;65:926-932.

$154 \mathrm{Li}$ J, Chen GS, Zhang X, Moore L, Cheng H: Congenital cystic adenomatoid malformation with associated mucinous bronchioloalveolar carcinoma in a neonate. Fetal Pediatr Pathol 2014;33:29-34.

155 Abecasis F, Gomes Ferreira M, Oliveira A, Vaz Velho H: Bronchioloalveolar carcinoma associated with congenital pulmonary airway malformation in an asymptomatic adolescent (in Portuguese). Rev Port Pneumol 2008; 14:285-290 